- Basic Research

\title{
Predominant Conflict Types and Resolution strategies among Nursing Student of Different Cultures
}

\author{
Samah F. Fakhry*1 and Sarah,S.A. El Deep2 \\ 1 Nursing Administration Department. Faculty of Nursing. Ain Shams University, Egypt. \\ 2 Nursing administration Department. Faculty of Nursing. Modern University for Technology \\ and Information, (MTI). \\ *dr.samah.faisal@nursing.asu.edu.eg
}

\begin{abstract}
Difference in cultures among student nurses may be sources of conflicts, which if excessive may jeopardize learning process. Aim: The aim of the study is to investigate predominant conflict types and resolution strategies among nursing students with different cultures. It was conducted on 162 Egyptian student and 54 Nigerian Students from all department of faculty of Nursing affiliated to Modern University for Technology and Information (MTI) using an cross sectional design. Methods: The data were collected using a self-administered questionnaire with Thomas-Kilmann Conflict mode Instrument (TKI).Results: The result revealed that the intergroup type of conflict was the most predominant ( $25.9 \%$ ) among Egyptian nursing students meanwhile inter personal type was the predominant conflict type among Nigerian students(24.1\%). Collaborating strategy was predominantly used among Egyptians (23,5\%) and Nigerians (24.1\%). Hence, different cultures could influence the type of conflict and its management style. Recommendations: The study recommends: co-curriculum activities and training courses in conflict resolutions strategies and different are urgently needed for all students (Egyptian and Nigerian students) to help them to cope with conflict and improve their conflict resolution strategies that which positively affect their achievement and commitment level.
\end{abstract}

Key words: Nursing student, conflict, conflict types, conflict resolution strategies, predominant 


\section{Introduction:}

Conflict is inevitable (Pickles et al., 2019). It is a constant variable within one's personal life and professional life (Ylitörmänen, 2015). Diversity is one of the key components of conflict. Organizations are comprised of individuals with a multitude of interests, beliefs, personalities, cultures, and values (Omisore and Abiodun, 2014; Mohamed and Yousef, 2014). As a group increases in size and diversity, the amount of conflict typically increases as well (Milton et al., 2015).

Conflict can be categorized according to situation into intrapersonal, interpersonal, intragroup, and intergroup types. It can also be positive or negative, healthy, or dysfunctional. A certain amount of conflict is beneficial to individuals as it can increase creativity by acting as a stimulus for developing new ideas or identifying methods for solving problems. It also helps people recognize legitimate differences within the organization or profession and serves as a powerful motivator to improve performance and satisfaction (Barr and Dowding ,2012).

Conflict resolution strategies which constitute the elements of a classification of different modes for handling interpersonal conflicts, have been identified as a source of reaching more favorable outcomes in a broad spectrum of different conflict situations (Lahana et al., 2017). Nurses used avoidance, compromise, and dominating styles depending on the contextual factors of perceived interrelationship between the members, and the urgency of acting regarding the situation (Labrague and McEnroe-Petitte, 2017). 
Nursing students experience higher levels of academic stress than those of other disciplines as they have to adapt to various clinical settings for practice and are exposed to diverse patient conditions as well as dying and death during placement (Reeve et al., 2013). Academic stress leads to psychological distress and has detrimental effects on well-being. In addition, nursing students must apply theoretical knowledge to practice to bridge the theory-practice gap (Thomas and Revell, 2016). They must cope with the emotional and academic demands of patient care (Reeve et al., 2013).

\section{Significance of the study}

Conflict resolution strategies are valued in nursing education as a means of fostering teamwork and collaboration among health care professionals. This value is based on two assumptions. First, conflicts faced by students in nursing faculties have a direct effect on performance as well as the outcome of learning experience. Second, the responsibility of nursing faculties is to increase the ability and competency of their students to establish working relationships with diverse individual and groups of people as future professionals. As conflict types and resolution depend on the cultural and environmental issues within the organization, it was important to investigate predominant conflict types and resolution strategies among nursing students with different cultures

\section{Aim of the study}

This study aimed to investigate predominant conflict types and resolution strategies among nursing students with different cultures at the Faculty of Nursing affiliated to the Modern University for Technology and Information (MTI) 


\section{Operational definition:}

The term predominant means having superior strength, influence, authority or being most frequent or common

\section{SUBJECTS AND METHODS:}

The aim of the study was to investigate predominant conflict types and resolution strategies among nursing students with different cultures The methodology followed in carrying out the study is presented under technical, operational, administrative, and statistical designs.

\section{TECHNICAL DESIGN}

The technical design entails a description of the research design, study setting, subjects, and tools of data collection.

\section{Research design}

A cross-sectional analytic design was used in carrying out this study where all dependent and independent variables are measured at the same point in time, with no prospective or retrospective follow-up.

\section{Setting}

The study was conducted at the Faculty of Nursing affiliated to the Modern University for Technology and Information (MTI). The faculty has six departments, namely medical-surgical, pediatric, obstetric, psychiatric, community health nursing departments, in addition to the nursing administration department. 


\section{Subjects}

Sample criteria: All full-time Egyptian and Nigerian students enrolled in the Faculty of Nursing, MTI University during the academic year 2019/20 were eligible for inclusion in the study. Their total number was 512 Egyptian students and 70 Nigerian students.

Sample size: The sample size was calculated to estimate a correlation coefficient of 0.20 (Pines et al, 2011) or higher with $80 \%$ power and at a $95 \%$ level of confidence between the scores of conflict management and resilience. Using the sample size equation for correlation in Open Epi software package, the required sample size is 194. This was increased to 210 to account for a non-response rate of about $10 \%$. Since the total number of Nigerian students was 70, the sample included all of them in addition to 140 Egyptian students in a 1:2 ratio. However, at the time of data collection, the total number of Nigerian students decreased to 54. Therefore, the sample size distribution was re-adjusted to include all 54 Nigerians in addition to 162 Egyptian students, in a ratio of $1: 3$, for a total sample 216 students.

\section{Sampling technique:}

All 54 Nigerian students were enrolled in the study with no sampling. As for the Egyptian students, a stratified random sampling technique was used to recruit equal numbers of students from all eight semesters. Therefore, 20 students were randomly selected from each of the eight semesters. However, to fulfill the required sample size, 21 students were recruited from each of the fifth and sixth semesters. 


\section{Data collection tool:}

The researcher used a self-administered questionnaire namely a conflict mode instrument, the self-administered questionnaire form consisted of the following parts:

Part I: This was for collection of data about the personal characteristics of the nursing students such as the academic year and semester, age, gender, pre-university education, marital status, previous study of conflict, and work during study.

Part II: Conflict mode instrument: This tool was used in identifying the types of conflicts students face, and the conflict management styles used. The tool thus includes two sections as following.

Section 1: Types Conflict Measurement Form: This form was developed by Thomas et al (1974) to measure conflict and to determine its types. It includes 16 items equally subdivided into four scales of 4 items each.

o Intrapersonal conflict: e.g. "teacher often demand that I do things I simply cannot do", etc.

o Interpersonal conflict: e.g. "other students often disagree each other about how work on these lectures should be handled", etc.

o Intergroup conflict: e.g. "support educational services are readily available when I need them", etc.

o Intragroup conflict: e.g. "I frequently encounter problems when I transfer to other training unit or departments", etc.

Scoring: The items are checked on a five-point Likert scale ranging from "seldom" to "always." These are scored from 1 to 5 respectively. For each type, the scores of the items were summed-up and the total divided by the 
number of items, giving a mean score for the part. Then, these scores were converted into percent scores. The respondent' exposure to the type of conflict was considered high if the percent score was $60 \%$ or higher, and low if $<60 \%$. Moreover, the predominant type of conflict faced by the student was defined as the type having the highest total score.

Section 2: Conflict Resolution Strategies Form: This was aimed at identifying the conflict resolution strategies used by the nursing students. It was developed by Huber (2010); Marquis and Huston, 2012). The scale consists of 30 items equally divided into five styles with six items each as following.

o Avoiding: such as "1. I avoid being "put on the spot"; I keep conflicts to myself", etc.

o Competing: such as "2. I use my influence to get my ideas accepted", etc.

o Compromising: such as " 3 . I usually try to "split the difference" in order to resolve an issue", etc.

o Accommodating: such as " 4 . I generally try to satisfy the other's needs", etc.

o Collaborating: such as " 5 . I try to investigate an issue to find a solution acceptable to both of us", etc.

Scoring: The items are checked on a five-point Likert scale from "strongly disagree" to "strongly agree." These are scored from 1 to 5 respectively. For each type, the scores of the items were summed-up and the total divided by the number of items, giving a mean score for the part. These scores were converted into percent scores. The respondent' use to the conflict resolution style was considered high if the percent score was $60 \%$ or higher, and low if $<60 \%$. Additionally, the predominantly used style of conflict resolution was defined as the style having the highest total score. 


\section{OPERATIONAL DESIGN}

The operational design includes the details of the preparatory phase, pilot study, and fieldwork.

\section{Preparatory Phase:}

The researcher reviewed the current and past, national and international related literatures in order to be more acquainted with the theoretical background knowledge of the various aspects of the study topics. This was carried out using textbooks and articles in scientific journals, as well as internet search. This was necessary for the preparation of the data collection tools, and in writing the literature review.

Tool validity and reliability: For validation of the data collection form, the two scales used are standardized, and with known validity (Thomas et al, 1974, Pines et al., 2011; Tonkin, 2016). Moreover, several studies have supported their validity and reliability (Ben yoav and Banai, 1992; van de vliret and Kabanaff, 1990).

The reliability of the scales was tested in the present study by examining their internal consistency. The demonstrated good levels of reliability as shown below.

\begin{tabular}{|c|c|l|}
\hline Cronbach's Alpha & N of Items & \multicolumn{1}{|c|}{ Scales } \\
\hline 0.55 & 30 & Conflict styles \\
\hline 0.60 & 16 & Conflict types \\
\hline
\end{tabular}




\section{Pilot study}

A pilot study was carried out to test the clarity and applicability of the tool, and estimate the time needed to fill the questionnaire sheet. It was conducted on 22 of the nursing students representing about $10 \%$ of study sample. Since no modifications were done in the data collection tool, the pilot subjects were included in the main study sample.

\section{Fieldwork:}

After securing all needed official permissions, the researcher visited the study settings to recruit students. She introduced herself to them, explained the aim of the study and its procedures, and invited them to participate after informing them of their rights. Those who consented were handed the data collection form and instructed in how to fill it. The researcher was present all the time for any calcification. This was also necessary to avoid communication among students that would influence their responses. Then, the filled forms were collected, and the researcher checked each form to ensure completeness of data filling, the actual fieldwork lasted from 1 October to 31 December 2019. The work was done 3 days per week. The average time taken by each student to complete the questionnaire was 15-20 minutes. On average, 4 to 5 students completed forms per day.

\section{ADMINISTRATIVE DESIGN}

Before starting on study implementation, an official letter was issued from the Dean of the Faculty of Nursing,, Modern University for Technology and Information (MTI) University, to heads of departments, to obtain permission for carrying out the study. The letter explained the aim of study, and a copy of the data collection tool was attached to it. Moreover, the researcher met with the Faculty administration, explained the aim of the study and its procedures, and arranged for the schedule of data collection. 


\section{Ethical considerations}

Prior to study conduction, approval was obtained from he Faculty of Nursing, MTI University. Oral informed consents were obtained from the students. They were informed about their rights to refuse or withdraw from the study with no consequences. They were reassured about the anonymity and confidentiality of the information collected, and that it would be used only for the purpose of scientific research.

\section{STATISTICAL DESIGN}

Data entry and statistical analysis were done using SPSS

20. 0 statistical software package. Data were presented using descriptive statistics in the form of frequencies and percentages for qualitative variables and means and standard deviations and medians for quantitative variables. Cronbach alpha coefficient was calculated to assess the reliability of the developed tools through their internal consistency. Qualitative categorical variables were compared using chi-square test. Whenever the expected values in one or more of the cells in a $2 \times 2$ tables was less than 5, Fisher exact test was used instead. In larger than $2 \times 2$ cross-tables, no test could be applied whenever the expected value in $10 \%$ or more of the cells was less than 5 . Statistical significance was considered at $p$-value $<0.05$. 


\section{RESULTS}

Table 1: Demographic characteristics of nursing student in the two groups

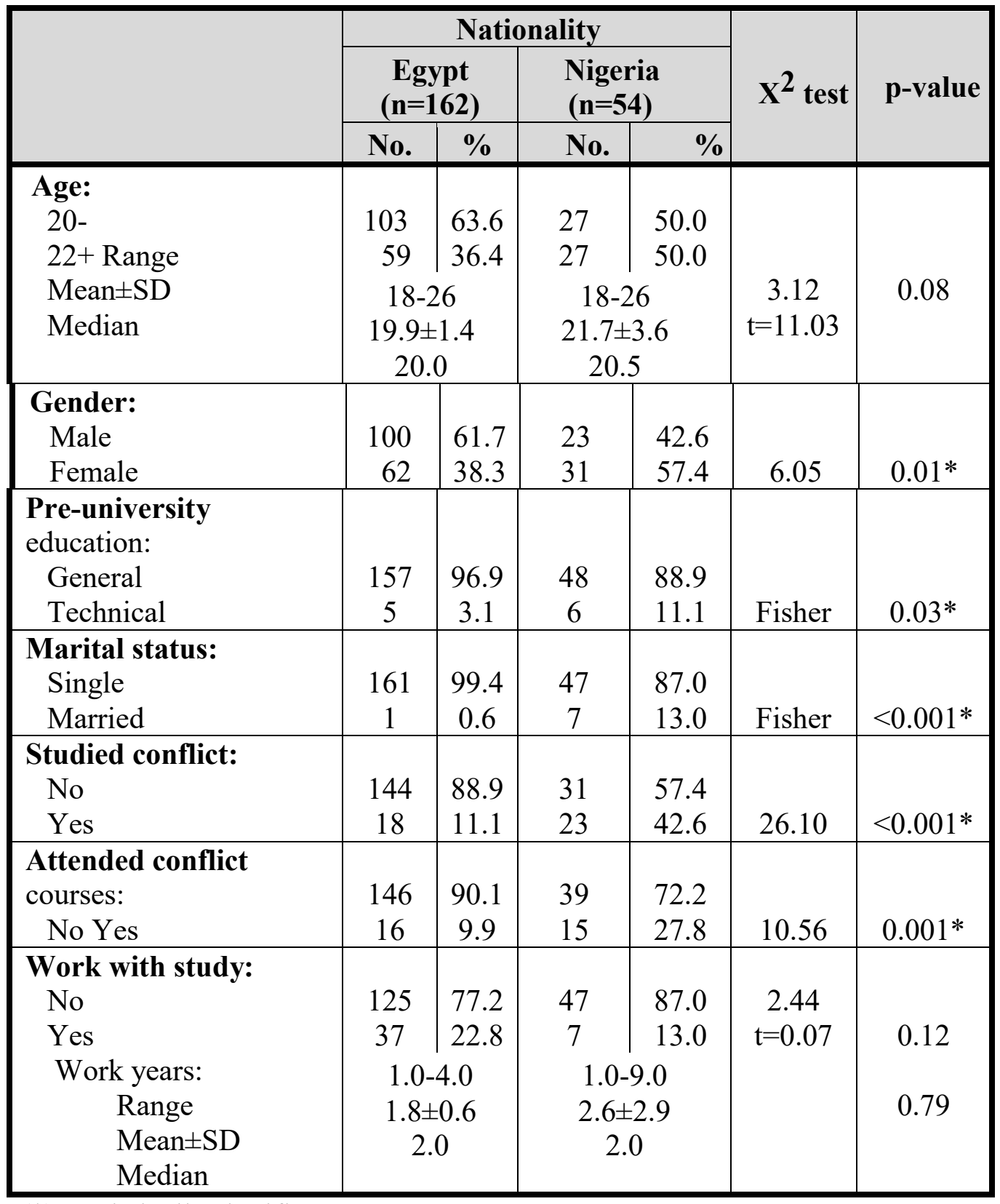

(*) Statistically significant at $\mathrm{p}<0.05$ 
The study comprised 162 Egyptian and 54 Nigerian nursing students. As shown in Table 1, they had similar age range and almost equal median age, with significantly more males in the Egyptian sample $(\mathrm{p}=0.01)$. Nigerian students had significantly more technical pre-university education $(\mathrm{p}=0.03)$, with more married ones $(p<0.001)$. Significantly higher percentages of them reported having studied conflict $(\mathrm{p}<0.001)$, or attended related courses $(\mathrm{p}=0.001)$. Meanwhile, more Egyptian students reported working during study, but the difference was not statistically significant.



Figure 1: Predominant types of conflict among nursing students in the two study groups.

Figure 1 illustrates that the highest percentages of nursing students in both groups were having a mix of the four types of conflict. Otherwise, the inter-group type was the most predominant among Egyptians, whereas the inter- 
personal type was the most predominant among Nigerians, and the difference was statistically significant $(\mathrm{p}=0.01)$.

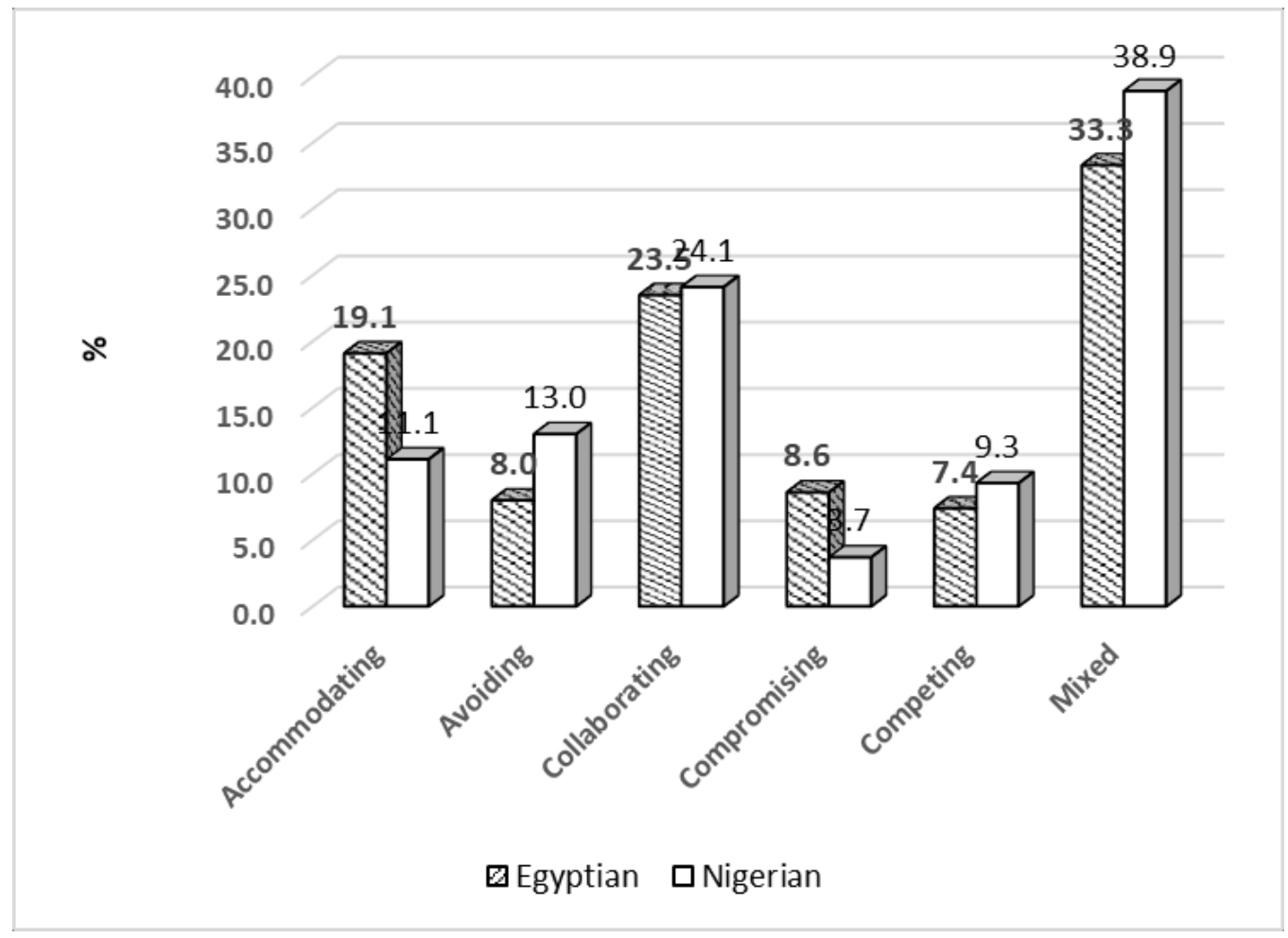

(*) Statistically significant at $\mathrm{p}<0.05$

Figure 2: Predominantly used conflict resolution strategies among nursing students in the two study groups.

As displayed in Figure 2, around one third or more of the nursing students in both groups were using a mix of the five conflict resolution strategies. Nonetheless, the collaborating style was the most predominantly used among Egyptians (23.5\%) and the Nigerians (24.1\%), with no statistically significant difference $(\mathrm{p}=0.48)$. 
Table 2a: Relations between Egyptian nursing students' use of collaborating strategy and their characteristics

\begin{tabular}{|c|c|c|c|c|c|c|}
\hline & \multicolumn{4}{|c|}{ Collaborating } & \multirow{3}{*}{$\mathrm{X}^{2}$ test } & \multirow{3}{*}{ p-value } \\
\hline & \multicolumn{2}{|c|}{ High } & \multicolumn{2}{|c|}{ Low } & & \\
\hline & No. & $\%$ & No. & $\%$ & & \\
\hline Age: & & & & & & \\
\hline 20 & 101 & 98.1 & 2 & 1.9 & & \\
\hline $22+$ & 58 & 98.3 & 1 & 1.7 & Fisher & 1.00 \\
\hline Gender: & & & & & & \\
\hline Male & 97 & 97.0 & 3 & 3.0 & & \\
\hline Female & 62 & 100.0 & 0 & 0.0 & Fisher & 0.29 \\
\hline Pre-university education: & & & & & & \\
\hline General & 154 & 98.1 & 3 & 1.9 & & \\
\hline Technical & 5 & 100.0 & 0 & 0.0 & Fisher & 1.00 \\
\hline Marital status: & & & & & & \\
\hline Single & 158 & 98.1 & 3 & 1.9 & & \\
\hline Married & 1 & 100.0 & 0 & 0.0 & Fisher & 1.00 \\
\hline Semester: & & & & & & \\
\hline 1 & 20 & 100.0 & 0 & 0.0 & & \\
\hline 2 & 19 & 95.0 & 1 & 5.0 & & \\
\hline 3 & 19 & 95.0 & 1 & 5.0 & & \\
\hline 4 & 20 & 100.0 & 0 & 0.0 & & \\
\hline 5 & 21 & 100.0 & 0 & 0.0 & -- & -- \\
\hline 6 & 20 & 95.2 & 1 & 4.8 & & \\
\hline 7 & 20 & 100.0 & 0 & 0.0 & & \\
\hline 8 & 20 & 100.0 & 0 & 0.0 & & \\
\hline Studied conflict: & & & & & & \\
\hline No & 141 & 97.9 & 3 & 2.1 & & \\
\hline Yes & 18 & 100.0 & 0 & 0.0 & Fisher & 1.00 \\
\hline Attended conflict courses: & & & & & & \\
\hline No & 143 & 97.9 & 3 & 2.1 & & \\
\hline Yes & 16 & 100.0 & 0 & 0.0 & Fisher & 1.00 \\
\hline Work with study: & & & & & & \\
\hline No & 122 & 97.6 & 3 & 2.4 & & \\
\hline Yes & 37 & 100.0 & 0 & 0.0 & Fisher & 1.00 \\
\hline
\end{tabular}

(--) Test result not valid 
Table 2b: Relations between Nigerian nursing students' use of collaborating strategy and their characteristics

\begin{tabular}{|c|c|c|c|c|c|c|}
\hline & \multicolumn{4}{|c|}{ Collaborating } & \multirow{3}{*}{$\begin{array}{c}X^{2} \\
\text { test }\end{array}$} & \multirow{3}{*}{$\begin{array}{c}\text { p- } \\
\text { value }\end{array}$} \\
\hline & \multicolumn{2}{|c|}{ High } & \multicolumn{2}{|c|}{ Low } & & \\
\hline & No. & $\%$ & No. & $\%$ & & \\
\hline Age: & & & & & & \\
\hline $20-$ & 26 & 96.3 & 1 & 3.7 & & \\
\hline $22+$ & 27 & 100.0 & 0 & 0.0 & Fisher & 1.00 \\
\hline Gender: & & & & & & \\
\hline Male & 23 & 100.0 & 0 & 0.0 & & \\
\hline Female & 30 & 96.8 & 1 & 3.2 & Fisher & 1.00 \\
\hline Pre-university education: & & & & & & \\
\hline General & 47 & 97.9 & 1 & 2.1 & & \\
\hline Technical & 6 & 100.0 & 0 & 0.0 & Fisher & 1.00 \\
\hline Marital status: & & & & & & \\
\hline Single & 46 & 97.9 & 1 & 2.1 & & \\
\hline Married & 7 & 100.0 & 0 & 0.0 & Fisher & 1.00 \\
\hline Semester: & & & & & & \\
\hline 1 & 7 & 100.0 & 0 & 0.0 & & \\
\hline 2 & 5 & 100.0 & 0 & 0.0 & & \\
\hline 3 & 2 & 100.0 & 0 & 0.0 & & \\
\hline 4 & 3 & 100.0 & 0 & 0.0 & -- & -- \\
\hline 5 & 9 & 90.0 & 1 & 10.0 & & \\
\hline 6 & 6 & 100.0 & 0 & 0.0 & & \\
\hline 7 & 6 & 100.0 & 0 & 0.0 & & \\
\hline 8 & 15 & 100.0 & 0 & 0.0 & & \\
\hline Studied conflict: & & & & & & \\
\hline No & 30 & 96.8 & 1 & 3.2 & & \\
\hline Yes & 23 & 100.0 & 0 & 0.0 & Fisher & 1.00 \\
\hline Attended conflict courses: & & & & & & \\
\hline No & 38 & 97.4 & 1 & 2.6 & & \\
\hline Yes & 15 & 100.0 & 0 & 0.0 & Fisher & 1.00 \\
\hline Work with study: & & & & & & \\
\hline No & 46 & 97.9 & 1 & 2.1 & & \\
\hline Yes & 7 & 100.0 & 0 & 0.0 & Fisher & 1.00 \\
\hline
\end{tabular}

(--) Test result not valid 
Tables $2 \mathbf{a}$ and $\mathbf{2 b}$, indicate the absence of any statistically significant relations between Egyptian and Nigerian students' use of the collaborating conflict resolution style and any of their characteristics.

\section{DISCUSSION}

The aim of the study was to investigate predominant conflict types and resolution strategies among nursing students with different cultures. It involved Egyptian and Nigerian students. The results revealed that the majority in both groups experienced high conflicts, used various conflict resolution strategies. Significant differences were revealed between the two groups in conflict types and conflict resolution strategies.

The present study samples of Egyptian and Nigerian nursing students revealed close similarity in most personal characteristics. The only significant differences were related to gender, where there were more males among Egyptian students, whereas more Nigerian students were married. This might be due to the increasing trend of male students enrolling in nursing study worldwide, and particularly in Egypt. These differences in characteristics might influence their experience of conflict and its management styles, as well as their resilience as shown in the study findings. The effect of gender on this career choice has been emphasized in a study in the United Kingdom (Whitford et al., 2020).

Moreover, significantly more Nigerian students reported having technical pre-university education. They also had more study of conflict, and attended more related courses. These variables have also explained some of the differences in their experience of conflict and its management, the study 
results demonstrated. The importance of the type and quality of pre-university education and its role in making student more able to adapt to university student life have been demonstrated in a study in South Africa (Burch et al., 2018).

Working during study in common among nursing students. The current study demonstrated a trend of more work during study among Egyptian students in comparison to Nigerians, although not significant. Working during study was also revealed as a factor significantly influencing conflict and resilience. In congruence with this, a study on international students in Australia demonstrated a significant impact of work during study on these students, with high work-study conflicts (Thamrin et al., 2019).

In the present study, the predominant type of conflict experienced by the nursing students was determined by the type having the highest score. When the scores of the four types were equal, this was considered mixed. Thus, the results revealed that the highest percentages of nursing students in both groups were having a mix of the four types of conflict. This reflects the multiplicity and variation of the sources and causes of conflict among them and the inter-relations among the different types, which is supported by the significant positive correlations among the four types of conflict.

Meanwhile, the Egyptian students' most predominant type of conflict was the inter-group type, whereas the inter-personal type was the most predominant among their Nigerian colleagues, and the difference was statistically significant. This might be explained by the differences in the numbers of students between the two nationalities. Thus, the large numbers of Egyptian students would allow the sub-division to many sub-groups, and this would increase the chances of inter-group conflicts. Such inter-group conflicts 
are often the result of the deterioration of peaceful intergroup relations because of biological and cultural factors as reported by De Dreu et al. (2020) in a Chinese study.

Like for the types of conflict, the present study attempted to determine the predominant type of conflict management styles utilized by the nursing students as the style having the highest score. When the scores of the four types were equal, the student was considered as using a mix of styles. The findings demonstrated that the highest percentages of nursing students in both groups were using a mix of the five styles. This indicates more maturity in dealing with conflict, since each situation may need a specific style that does not suit other situations.

Nonetheless, the collaborating conflict management style was found to be the most predominantly used among both the Egyptian and the Nigerian students. This might reflect more collegial relations that often prevails in this community of university students. This is one of the most constructive conflict management styles with win-win outcomes. The finding agrees with (Mosadeghrad and Mojbafan, 2019) whose study in Iran recommended this style among the most suitable ones to resolve conflicts in nursing.

\section{CONCLUSION}

The study findings demonstrate students 'experience of various types of conflict, which the highest percentage of nursing students were having mix of four conflict types of conflict however the inter-group type was the predominant among Egyptian and Nigerian nursing students, significantly more among the formers. The mix of the five conflict resolution strategies is 
the most used by both, with more use of the collaborating strategy by Egyptians. Hence, different cultures could influence the type of conflict and its management style.

\section{RECOMMENDATIONS}

- The importance of conflict management using positive constructive strategies should be included in undergraduate as well as postgraduate nursing curricula.

- Co-curriculum activities and training courses in conflict types and resolution strategies are urgently needed for all students; both Egyptian and international students improve their skills in managing conflicts.

- Nurse educators should ensure a healthy learning environment with open communication and should listen attentively to students facing conflicts.

- Management and staff of training places should demonstrate neutrality in students' placement and judging conflict between Egyptian and Nigerian or other international students with no biased inclination to either.

- Further research is proposed to examine the effectiveness of training of coping strategies on experience of conflict and its proper management. 


\section{References:}

Barr, J., \& Dowding, L. (2012). Leadership in Healthcare. London: SAGE Publications.pp:70-73

Burch VC, T Sikakana CN, Gunston GD, Whittle SR, Murdoch-Eaton D. PreUniversity education curriculum reform and the generic learning skills of medical school entrants: Lessons learned from South Africa. Educ Health (Abingdon). 2018;31(1):25-31. doi:10.4103/1357-6283.239043

De Dreu CKW, Gross J, Fariña A, Ma Y. Group Cooperation, CarryingCapacity Stress, and Intergroup Conflict [published online ahead of print, 2020 Jun 30]. Trends Cogn Sci. 2020; S1364-6613(20)30146-7. doi: $10.1016 /$ j.tics.2020.06.005

Labrague, L., \& McEnroe - Petitte, D. (2017). An integrative review on conflict management styles among nursing students: Implications for nurse education. Nurse Education Today, 59, 45-52.

Lahana, E., Tsaras, K., Kalaitzidou, A., Galanis, P., Kaitelidou, D., \& Sarafis, P. (2017). Conflicts management in public sector nursing. International Journal of Healthcare Management, 17. https://doi.org/10.1080/20479700.2017.13537

Milton, D. R., Nel, J. A., Havenga, W., \& Rabie, T. (2015). Conflict management and job characteristics of nurses in South African public hospitals. Journal of Psychology in Africa, 25(4), 288-296

Mohamed, F. R., \& Yousef, H. R. (2014). Emotional intelligence and conflict management styles among nurse managers at Assiut University Hospitals. International Journal: Educational and Practice, 5(5), 160165.

Mosadeghrad AM, Mojbafan A. Conflict and conflict management in hospitals. Int J Health Care Qual Assur. 2019;32(3):550-561. doi:10.1108/IJHCQA-09-2017-0165

Omisore, B. O., \& Abiodun, A. R. (2014). Organizational conflicts: Causes, effects and remedies. International Journal of Academic Research in Economics and Management Sciences, 3(6), 118-137.

Pickles D, Lacey S, King L. Conflict between nursing student's personal beliefs and professional nursing values. Nurs Ethics. 2019;26(4):1087-1100. doi:10.1177/0969733017738132 
Reeve KL, Shumaker CJ, Yearwood EL, Crowell NA, Riley JB. Perceived stress and social support in undergraduate nursing students' educational experiences. Nurse Educ Today. 2013;33:419-424. doi: 10.1016/j.nedt.2012.11.009.

Thamrin Y, Pisaniello D, Guerin C, Rothmore P. Correlates of Work-Study Conflict among International Students in Australia: A Multivariate Analysis. Int J Environ Res Public Health. 2019;16(15):2695. Published 2019 Jul 28. doi:10.3390/ijerph16152695

Thomas LJ, Revell SH. Resilience in nursing students: an integrative review. Nurse Educ Today. 2016;36:457-462. doi: 10.1016/j.nedt.2015.10.016.

Whitford HM, Marland GR, Carson MN, et al. An exploration of the influences on under-representation of male pre-registration nursing students. Nurse Educ Today. 2020;84:104234. doi:10.1016/j.nedt.2019.104234

Ylitörmänen, T. (2015). A web-based survey of Finnish nurses' perceptions of conflict management in nurse-nurse collaboration. International Journal of Caring Sciences, 8(2), 263-273. 


\section{الملخص العربي}

\section{أنواع الصراع السائدة واستراتيجيات الحل يين طلاب التمريض من ثقافات مختلفة}

I.د سماح فيصل فخري * ا وسارة سيد أحمد الديب r. dr.samah.faisal@nursing.asu.edu.eg*

المقدمه :قد يكون الاختلاف في التقافات بين طلاب التمريض مصدرًا للصر اعات ، و التي إذا كانت مفرطة قد تعرض عملهية التعلم للخطر. الهدف :هدفت الدر اسة إلى دراسه نوع الصر اعات و استر اتيجية حلها السائده بين طلاب التمريض من ثقافات مختلفة.

منهجيه البحث :تم إجراؤها على 162 طالبًا مصريًا و 54 طالبًا من جميع أقسام كلية التمريض التابعة للجامعة الحديثة للتكنولو جيا و المعلومات باستخدام تصميم مقطعي. أداه جمع البيانات:تم جمع البيانات باستخدام استبيان ذاتي المليء باستخدام أداة قياس

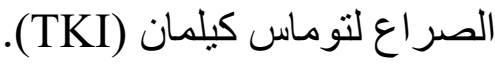

التتائج :أظهرت النتيجة أن نوع الصراع بين المجموعات كان الأكثر انتشارًا (25.9٪)

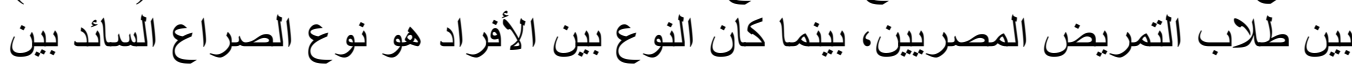
الطلاب النيجيريين (24.1\%). تم استخدام الإستراتيجية التعاونية في الغالب بين المصرين الاين (23.5\%) و النيجيريين (24.1\%). وبالتالي ، يمكن للثقافات المختلفة أن تؤثر على نوع الصر اع و أسلوب إدارته.

التوصيات: توصي الدر اسة بما يلي: هنالك حاجة ماسة لأنشطة المناهج المشتركة ودور ات

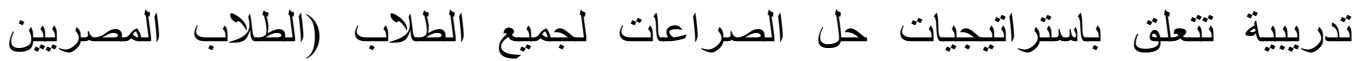

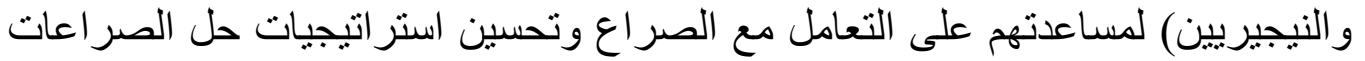
لديهم التي تؤثر بشكل إيجابي على مستوي إنجاز هم والتز امهم كلمات البحث : طالب تمريض، صراع , انواع الصراع السائدة، الأختلاف الثقافي

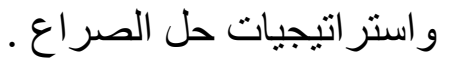

